campanii de prevenție. În timp ce capitolui 12 subliniază importanța cunoaşterii inferențelor pentru o prevenire mai eficientă a accidentelor, capitolul 13(Dongo Rémi Kouabenan) ridică în schimb o întrebare importantă: este suficient ca un angajat să perceapă riscul pentru a adopta un comportament de protecție în locul unuia nesigur? De asemenea, tot în acest capitol, autorul discută şi aspectele practice ale mesajelor campaniilor de prevenție. Pentru a schimba atitudini, este necesar ca argumentele cuprinse în mesaj să ia în considerare explicațiile cauzale şi motivația indivizilor de a adopta un comportament sigur. Mai mult, autorul accentuează cât este de important să ținem cont şi de contextul social şi organizațional în care au loc accidentele.

În concluzie, diversitatea studiilor psihologice cuprinse în acest volum permite celor interesați să-şi formeze o perspectivă de ansamblu asupra evoluției studiilor psihologice privind percepția riscurilor. Mai mult, ideile şi sugestiile de aplicare ale cunoştințelor rezultate din aceste studii sunt utile practicienilor care se ocupă de siguranța transporturilor, protecția muncii şi prevenția accidentelor de muncă.

\section{Maura GORAŞ}

Frank, J. Landy \& Jeffrey, M. Conte (2007). Work in the 21st Century. An Introduction to Industrial and Organizational Psychology. Blackwell Publ., Malden: MA, USA

Frank Landy este profesor emerit în psihologie industrială şi organizațională la Penn State University, una dintre personalitățile active în domeniu, cu o activitate didactică, publicistică şi de consultanță, prestigioasă. Jef Conte, unul dintre numeroşii discipoli ai lui Frank Landy, este professor asociat al departamentului de psihologie al Universității de Stat din San Diego. Este implicat, de asemenea, în consultanță, fiind un cunoscut cercetător în domeniul selecției de personal, al trăsăturilor de personalitate ca predictori ai performanței, managementul timpului, măsurarea inteligenței emoționale, şi al factorilor implicați în sănătate şi stres ocupațional. A publicat numeroase articole de specialitate în reviste de prestigiu din domeniul psihologiei muncii şi organizaționale.

Lucrarea pe care o prezentăm este a doua ediție, mult amplificată şi restructurată față de ediția din 2004. Ea include noile tendințe din psihologia industrială şi organizațională $(I / O)$, bazându-se pe cercetări recente în domeniu. Pentru psihologii din România, această lucrare va constitui un ghid esențial, constituindu-se (alături de prima ediție) ca bază pentru cursul de psihologia muncii de la Universitatea BabeşBolyai din Cluj-Napoca.

Față de ediția anterioară, aceasta din urmă aduce o serie de îmbunătățiri. Astfel, referințele bibliografice sunt de dată foarte recentă, numărul de pagini este mai redus, textul fiind concentrat, dar exemplificările sunt mai numeroase. Sunt oferite numeroase repere pentru proiectarea unor cercetări, cititorii fiind stimulați să se implice în astfel de acțiuni. Totodată, această apariție editorială include şi o serie de subiecte noi despre problema sindicatelor, a acționarilor, motivarea antreprenorilor, identificarea cu organizația, plata orelor suplimentare, şi practicile corecte de salarizare, precum şi măsurarea atitudinii față de Internet. Autorul abordează şi aspecte ce țin de comportamentul cetățenesc, comportamentul contraproductiv la locul de muncă, utilizarea evaluărilor situaționale în aprecierea performanțelor, competențele, interviul comportamental, leadership-ul transformațional, autoevaluarea performanțelor şi feedback-ul de 360 de grade. Pentru facilitarea înțelegerii noțiunilor expuse, autorii utilizează numeroase exemple şi ilustrări din diferite experimente şi cercetări aferente domeniului psihologiei I/O.

Principalele capitole ale lucrării sunt următoarele: Ce este psihologia industrială şi organizațională; Metode şi statistici în psihologia I/O; Diferențele individuale şi măsurarea lor, Înțelegerea noținii de performanță; Măsurarea performanței; Deciziile de personal; Instruire şi dezvoltare profesională; Motivarea în muncă; Atitudini, emoții şi muncă; Stresul şi sănătatea personalului; Corectitudinea (fair-play) şi diversitatea la locul de muncă; Leadership-ul; Echipele în organizații; Organizarea comportamentului în muncă.

Capitolul 1, Ce este psihologia industrială şi organizațională, este o reuşită introducere în psihologia $\mathrm{I}-\mathrm{O}$, autorii explicând contribuția acesteia la dezvoltarea societății. Abordând domeniul din punct de vedere istoric, la contribuția țărilor europene este menționată şi România, la fel ca şi în ediția precedentă. Autorii prezintă apoi principalele domenii de activitate ale psihologilor din SUA: academic (38\%), consultanță $(23 \%)$ şi sectorul privat $(28 \%)$. În 2005, salariul mediu al unui psiholog cu doctorat era de 87000 USD, iar al unui psiholog cu masterat de 65000 USD. Un spațiu considerabil este acordat problemelor multiculturale şi 
cercetărilor psihologice inter-culturale, cercetări care în țara noastră sunt în faza de debut.

Capitolul 2 discută despre Metode şi statistici în psihologia //O. Este o bună oportunitate pentru cei care studiază acest domeniu al psihologiei să parcurgă un spațiu util oricărui psiholog practician: necesitatea abordării ştiințifice a psihologiei I-O, problema generalizării rezultatelor şi controlul cercetărilor, alături de conținutul comportamentului etic în psihologia I-O şi riscurile nerespectării sale. Sunt discutate problemele statistice fundamentale (descriptive), fără a le neglija însă pe cele avansate (metaanaliza). Un modul separat este dedicat metodelor de interpretare a datelor, accentuându-se importanța fidelității şi a validității măsurătorilor.

Capitolul 3, Diferențele individuale şi măsurarea lor, face o trecere în revistă a unui domeniu de prim interes pentru psihologii I-O. De fapt, sunt enunțate teoriile noi care au fost dezvoltate în domeniul aptitudinilor generale şi specifice şi taxonomiile acestora. Se abordează problema personalității din perspectiva Big-Five şi a testării intereselor ocupaționale. Autorii susțin necesitatea organizării unor studii legate de validarea predictivă a trăsăturilor de personalitate şi intereselor în predicția performanțelor profesionale. Este interesantă opinia rezervată a autorilor față de exagerările legate de inteligența emoțională; se subliniază lipsa de consistență a cercetărilor pe această problemă care entuziasmează poate prea mult psihologii practicieni.

Capitolele 4 şi 5 tratatează una din aspectele importante cu care se confruntă psihologii I-O: Înțelegerea noținii de performanță şi Măsurarea performanței. Este discutat în primul rând modelul fundamental al performanței propus de Campbell şi extensiile acestuia. Tot aici este dezvoltată şi problema analizei şi evaluării muncii. Capitolul este dens şi oferă numeroase informații şi soluții utile. În Capitolul 5, cele 4 module se ocupă de câteva concepte de bază în măsurarea performanțelor, plecând de la tipurile de date de performanță şi până la monitorizarea electronică a performanței sau percepțiile față de astfel de măsurători. Sunt discutate sistemele de evaluare a performanțelor şi procesele aferente acestora (sursele de evaluare, distorsionarea evaluărilor, instruirea evaluatorilor, validitatea şi fidelitatea evaluărilor). Implicațiilor etice, a cadrului legal care trebuie respectat, li s-a acordat un spațiu larg. Este o problemă crucială căreia la noi nu i se dă o importanță prea mare, fiind deseori neglijată, fapt ce lasă loc abuzurilor.
Capitolul 6 se ocupă de deciziile de personal. Este un capitol foarte sistematizat, probabil datorită faptului că autorii au tratat problema ca şi când ar fi cunoscută de cititor. Problemele deciziei de personal sunt complexe, în timp fiind dezvoltate metode de intervenție sensibile, bazate pe o statistică şi metode sofisticate (Guion \& Highhouse, 2006; McPhail, 2007; Ployhart, Schneider \& Schmitt, 2006). Un aspect demn de subliniat este faptul că şi aici este accentuată legalitatea intervențiilor psihologice.

Capitolul 7 abordează problema instruirii profesionale. Ceea ce este semnificativ e faptul că trainingul este legat de performanță. Totodată, importanța acestui subiect creşte şi prin aceea că adevărata pregătire profesională nu se mai realizează în şcoală, care reuşeşte să dea doar un cadru profesional general, ci la nivel de companie, unde instruirea primeşte dimensiuni noi, nu numai strict profesionale, dar şi de cultură organizațională. Autorii păstrează modelul de instruire propus de Goldstein şi pe baza lui dezvoltă o schemă a instruirii. Fiecare componentă a modelului este analizată din punct de vedere psihologic, oferindu-se totodată şi soluții pertinente. Subliniem ca un paragraf interesant, problema instruirii la distanță. Evaluarea instruirii constituie şi ea un subcapitol important la fel şi programele de training specializate.

Ultima parte a cărții este dedicată psihologiei organizaționale: 7 capitole care acoperă aspectele importante ale domeniului organizațional. Noțiunile oferite sunt fundamentale, bazate pe ultimele descoperiri în această arie de intervenție.

Capitolul 8 se ocupă de problema motivației pentru muncă. Istoria problemelor de motivare a angajaților este veche. Poate din această cauză este şi un capitol bine documentat şi argumentat în psihologia organizațională. Autorii insistă atât asupra unei abordări istorice cât şi a unei prezentări dinamice a teoriilor despre motivația la locul de muncă. Reținem mai ales paragraful despre problemele practice pe care le ridică motivația şi aici strategiile de măsurare şi intervenție motivațională.

În capitolul 9, Atitudíni, emoții şi muncă, este dezbătută una dintre cele mai recente abordări din psihologia muncii: rolul emoțiilor în procesul muncii. În primul rând, autorii tratează problema satisfacției cu munca evocându-se studiile Western Electric efectuate de E. Mayo la fabrica "Hawthorne" şi care au dus la ceea ce s-a numit "Efectul Hawthorne". Desigur, cercetările moderne au progresat atât pe ideea construirii 
unor modele ale satisfacției profesionale/cu munca, dar şi a metodelor de diagnoză, în prezent foarte diversificate. Se trece apoi la probleme de actualitate din domeniu: dispoziții afective, emoții şi atitudini, şi modalitățile în care acestea pot influența satisfacția cu munca. Este asociat conceptul de ataşament față de organizație în relație nemijlocită cu atitudinile şi emoțiile. Sunt analizate şi alte comportamente conexe problemelor afective: pierderea locului de muncă, munca la domiciliu (telecommuting), echilibrul muncă-familie.

Capitolul 10 tratează problema stresului şi a stării de bine (well-being). Stresul la locul de muncă a generat în ultimii 20 de ani numeroase studii, aceasta datorită conexiunii lui cu problemele de sănătate şi a implicațiilor multiple pe care le are. Teoriile şi modelele despre stres sunt numeroase. Totuşi, în acest domeniu, s-a conturat rolul jucat de particularitățile individuale şi Tipul A de comportament. Aceasta a impus adoptarea unui pachet de tehnici de reducere şi management al stresului. Stresul rămâne în prezent unul dintre fenomenele cu multiple rezultante printre care, pe lângă cele de sănătate se remarcă şi comportamentele agresive concretizate în sintagma violenței la locul de muncă.

Capitolul 11 se ocupă de o temă interesantă, apărută de curând în atenția psihologilor, Corectitudinea (fair-play) şi diversitatea la locul de muncă. Problema respectării legalității acțiunilor psihologice, dar şi a practicilor manageriale, a primit în ultimul timp o atenție deosebită. Angajații au devenit mult mai atenți şi reactivi la actele de injustiție din organizații la care, de multe ori şi psihologii devin părtaşi. Astfel, în SUA s-a dezvoltat o adevărată metodologie de apărare a intereselor angajaților, de protejare a acestora fată de ilegalitățile comise de angajatori. Autorii acestei lucrări tratează acest subiect cu multă competență, Frank Landy fiind cunoscut ca unul din experții în domeniu.

Capitolul 12 se ocupă de problema conducerii (leadership-ul). După o clarificare a conceptelor legate de problema conducătorului şi a conducerii, autorii explică principalele teorii care s-au conturat începând cu anii 1920, când a fost promovată teoria portretelor bazate pe trăsături, urmată de studiile de la Ohio axate pe abordarea din punct de vedere al comportamentului, sau al comportamentului participativ promovată de studiile de la Michigan etc. Sunt trecute în revistă câteva modele mai semnificative ale conducerii. Un subcapitol este dedicat noilor abordări ale leadership-ului. Astfel este explicată teoria despre leader ca membru al schimbării (LMX). De asemenea este discutată teoria leader-ului transformațional şi a leader-ului charismatic. În final, autorii se ocupă de problema conducătorului într-o lume în care schimbările sunt foarte rapide, unde piața muncii are o dinamică accentuată şi în care locurile de muncă nu mai au granițe bine delimitate. O temă aparte care este dezbătută este paralela dintre femeia şi bărbatul în poziție de leader, la fel, a trăsăturilor lor de personalitate. Problematica interculturală şi diversitatea mediului în care acționează un leader este abordată sintetic.

Capitolul 13 discută problema Echipelor în organizații. Autorii fac distincție între "grup" şi "echipă" ocupându-se preponderent de ultima. Reținem discuția despre echipele virtuale şi apoi subcapitolul legat de problema eficienței echipei. Separat este dedicat un spațiu mai mare problemelor speciale conectate $\mathrm{cu}$ echipele: evaluarea performanțelor şi feedback-ul, rolurile şi dezvoltarea echipelor, instruirea echipelor şi aspecte culturale legate de activitățile de echipă.

Ultimul capitol, al 14-lea tratează paralela dintre organizație şi comportamentul de muncă. Autorii discută teoriile organizației, vorbesc despre climatul şi cultura organizațională şi noile orientări privitor la acestea. Nu lipseşte în final un subcapitol important, acela al schimbării organizaționale. Ceea ce marchează acest subcapitol este încercarea de a oferi o serie de informații practice privitor la conducerea procesului de schimbare, indiferent că este vorba de MBO, TQM, sistemul matrix sau sistemele Sigma. Sunt punctate succint şi principiile dezvoltării organizaționale.

Lucrarea, care conține 623 de pagini, se încheie cu un glosar de termeni, o listă bibliografică impresionantă, un index de autori şi unul pe subiecte. Editura Blackwell pune la dispoziția cititorului un manual al instructorului şi un manual al studentului, un set de teste de cunoştințe bazate pe întrebări cu răspunsuri la alegere şi, pentru fiecare capitol un set de slide-uri care să faciliteze expunerea coerentă a materialului.

Apreciem această lucrare ca deosebit de valoroasă pentru studenți şi psihologii practicieni. Ea permite o orientare eficientă în problemele psihologiei muncii şi organizaționale şi face sugestii prețioase pentru cercetarea fenomenului social din organizații.

\section{Horia D. Pitariu \& Andrea Budean}

\section{Bibliografie}

Guion, R.M. \& Highhouse, S. (2006). Essentials of personnel assessment and selection. Mahwah, NJ: LEA. 
McPhail, M.S., (Ed.) (2007). Alternative validation strategies. Developing new and leveraging existing validity evidence. San Francisco: Willey.

Ployhart, R.E., Schneider, B. \& Schmitt, N. (2006). Staffing organizations: Contemporary practice and theory. Mahwah, NJ: LEA.

Laura L. Koppes, Paul W. Thayer, Andrew J. Vinchur \& Eduardo Salas (Eds.) (2007). Historical Perspectives in Industrial and Organizational Psychology. Lawrence Erlbaum Associates

\begin{abstract}
Volumul Perspective istorice în Psihologia Industrială şi Organizațională (Historical Perspectives in Industrial and Organizational Psychology), editat de Laura L. Koppes şi apărut în 2007 la Lawrence Erlbaum Associates, este probabil unul dintre cele mai aşteptate volume ale anului 2007, în rândul specialiştilor din zona industrial-organizațională şi a resurselor umane. Volumul umple un gol foarte mare, într-o sferă care este asociată culturii profesionale şi anume în sfera istoriei psihologiei muncii, industriale şi organizaționale. Fiind o simplă tratare istorică, fără a reprezenta un compendiu sau ghid tehnic pe o anume temă din această arie ştiințifică şi fără a fi o culegere de bune practici, cartea contribuie remarcabil la creionarea unei culturi profesionale. Ea va deveni probabil în scurt timp o lectură obligatorie pentru studenți şi o lectură plăcută pentru practicienii acestei zone.
\end{abstract}

Laura L. Koppes este preşedinte al LK Associates, o companie de resurse umane, consultanță în leadership şi dezvoltare organizațională. De asemenea, ea este editorul actual al TIP (The Industrial-Organizational Psychologist), publicația oficială a SIOP (Society for Industrial-Organizational Psychology). Laura Koppes este cea care a fondat postul de Istoric pentru această asociație.

Volumul reprezintă rezultatul unei munci în colaborare, realizat de-a lungul mai multor ani şi la care au contribuit un număr mare dintre cei mai cunoscuți oameni de ştiință din acest domeniu de studiu. Pentru munca depusă la acest volum, editorul menționat a invitat pentru contribuții o seamă dintre cei mai prestigioşi autori şi cercetători activi astăzi în domeniul psihologiei industriale şi organizaționale. Paul W. Thayer, Andrew J. Vinchur şi Eduardo Salas sunt editori asociați, iar printre cei 28 de autori mai enumerăm nume sonore, precum John $P$.
Campbell, John Kantor, Gary Latham, Herbert $\mathrm{H}$. Meyer, Mark A. Wilson şi alții. Este interesant de menționat faptul că, deşi volumul are o mare valoare arhivistică, fiind un punct de vedere suficient de obiectiv asupra evoluțiilor istorice, fiecare autor a fost îndemnat să îşi imprime propria perspectivă asupra evoluțiilor istorice discutate. Autorii au avut de luat propriile decizii cu privire la ce anume să includă şi ce anume să excludă din lucrarea lor, precum şi la concluziile pe care să le sublinieze şi la modalitatea prin care să le argumenteze cu date şi fapte.

Volumul este împărțit în şase părți distincte: (i) Începuturi, (ii) Sinteze istorice, (iii) Influențe din zone educaționale, organizaționale şi militare, (iv) Probleme de cercetare timpurii, (v) Probleme de cercetare recente şi (vi) Reflecții pentru viitor. De asemenea, volumul conține în final o parte voluminoasă cu anexe.

Prima parte se concentrează asupra începuturilor intereselor pentru psihologia muncii şi industrială, care sunt asociate într-o mare măsură începuturilor psihologiei, având multe confluențe cu zona psihofiziologiei şi a psihologiei experimentale. Sunt identificate acele evenimente şi acei cercetători care prin munca lor, dezvoltând noi metodologii şi aplicându-le la problematica muncii umane şi a vieții în organizații, au dat o semnificație concretă şi empirică acestei noi discipline. Nu e de mirare că un rol central în acest sens este ocupat de studiile desfăşurate sub patronajul armatei americane.

Deşi volumul se concentrează preponderent asupra evolutiiilor petrecute în Statele Unite, a doua parte conține şi un capitol care se opreşte asupra evoluțiilor internaționale din domeniu, subliniind evenimente şi autori nonamericani, de exemplu din Europa sau chiar din Europa de Est.

Partea a treia tratează din perspectivă istorică diverse influențe majore asupra psihologiei organizațiilor, venind de la structura mediului academic, dar şi dinspre diverse organizații private sau publice. Un capitol interesant este cel care se concentrează pe programele academice care au oferit sau oferă formare în domeniul psihologiei muncii, industriale sau organizaționale în Statele Unite. Acest istoric este unul fascinant, pentru că oferă o viziune asupra modului în care educația superioară, academică, în acest domeniu, s-a dezvoltat în Statele Unite până la nivelul de neegalat şi de invidiat la care se plasează astăzi. Sunt, de asemenea, subliniate aici presiunile formale şi influențele informale pe care diverse organizații externe le-au avut asupra dezvoltării 